Editorial

\title{
Enacting Citizenship and the Right to the City: Towards Inclusion through Deepening Democracy?
}

\author{
Helen Hintjens * and Rachel Kurian \\ International Institute of Social Studies, Erasmus University Rotterdam, 2518 AX The Hague, The Netherlands; \\ E-Mails: hintjens@iss.nl (H.H.), kurian@iss.nl (R.K.) \\ * Corresponding author
}

Submitted: 20 November 2019 | Published: 28 November 2019

\begin{abstract}
In this introductory article, the main theoretical concerns guiding this thematic issue are briefly discussed, alongside an overview of relevant literature on rights and urban citizenship. We draw on the work of Engin on 'enacted citizenship,' and combine Hannah Arendt's 'right to have rights' with Henri Lefebvre's 'right to the city,' for inspiration. The hope is that these concepts or theoretical tools help our contributors explore the 'grey areas' of partial inclusion and exclusion, and to connect the informal with the formal, migrants with professionals, locals with those from elsewhere. Since the contributions in this issue come from practitioners as well as scholars, we are interested in very different forms of urban citizenship being enacted in a range of settings, in such a way as to overcome, or at least side-step, social, economic and political exclusion within specific urban settings. In this introduction we reflect on urban migrants organising and mobilising to enact their own citizenship rights within specific urban spaces, and present each of the eight published articles, briefly illustrating the range of approaches and urban citizenship issues covered in this thematic issue. The examples of urban enacted citizenship practices include efforts to construct economic livelihoods, gain access to health care, promote political participation, reweave the social fabric of poor neighbourhoods, and provide sanctuary. All of which, our contributors suggest, requires the engagement of the local urban authorities to allow room for the informal, and to accept the need for improved dialogue and improved access to public services.
\end{abstract}

\section{Keywords}

cities; European cities; enacted citizenship; health; local government; right to the city; sanctuary

Issue

This editorial is part of the issue "Inclusion through Enacted Citizenship in Urban Spaces" edited by Rachel Kurian (Erasmus University Rotterdam, The Netherlands) and Helen Hintjens (Erasmus University Rotterdam, The Netherlands)

(C) 2019 by the authors; licensee Cogitatio (Lisbon, Portugal). This article is licensed under a Creative Commons Attribution 4.0 International License (CC BY).

\section{Introduction}

Citizenship is enacted through not only legal but also cultural, social, economic and symbolic rights, responsibilities and identifications. (Isin, 2013, p. 19)

Our premise is that urban citizenship extends 'beyond law.' Once it becomes widely accepted-if perhaps tacitly-by urban residents that all those who live in the city should possess, for example, the right to basic health care, or secure housing, formal rights no longer equate with entitlements (if they ever do). Political or- ganising is fundamental to rights-claiming strategies in urban spaces, since, as Engin F. Isin points out, "people do not often mobilise and rise for abstract or universal ideals" (Isin, 2013, p. 22). Urban migrants and poorer residents are no exception. Legal rights do not define or delimit the contours of urban citizenship in practice. Particularly for those who are socially marginalized, they tend to organize to make very specific demands around the attributes and services connected with urban citizenship. Furthermore, "what all these actions come to mean collectively" can help inform all of us "about our own social and political lives" as urban residents (Isin, 2013, 
p. 22), whether we are migrants or not, refugees or not, legally resident or not. Enacted citizenship moves 'beyond the law' to assert that all urban residents have the 'right to rights' (Arendt, 1973).

The articles here presented draw on examples of local citizenship practices from different cities and regions. The researchers brought together in this thematic issue explore the local-level tensions, harmonies, strategies and dissonances that arise when migrants excluded from specified citizenship rights mobilise alongside citizens to claim their rights. The cases bring together local inhabitants, professionals, municipal workers, legal migrants, undocumented people and refugees, within a range of urban settings, with the focus mainly on cities in Western and Southern Europe. The aim has been to elucidate how practices and measures that promote protection and enjoyment of certain basic rights for all, whether the right to a livelihood, to health, to an associational life or to mobility are selectively negotiated and organised.

What the city has to offer to its legal and its longerterm undocumented residents, to recent migrants and 'locals' alike, is not given, but is the outcome of citizenship, solidarity and self-organisational struggles and setbacks. Social inclusion is a process, therefore, from this perspective, that should enable individuals and groups to claim their basic rights in the cities in which they live. Arguably, mobilisation is needed for migrants even to conceive of their rights to the city in the first place. The next step will be how such claim to certain rights are framed and presented. This approach takes fully on board the interlocking social, economic, political and cultural forms of exclusion and inclusion. These, in turn, influence which citizenship rights different 'categories' of residents of a particular city, or set of cities, can or cannot enjoy. The idea of 'enacted citizenship' as elaborated by Isin, is of obvious relevance to the on-going need for mobilisation among different categories of disenfranchised people who live in cities, and yet do not benefit from economic, social and political inclusion. Accompanying this, we propose that in establishing rights to full urban citizenship, Henri Lefebvre's suggestive notion of 'the right to the city' can also open up analytical perspectives that may be of more general interest to those interested in the politics of urban social inclusion and exclusion (Kofman \& Lebas, 1996, pp. 147-158).

The articles in this thematic issue seek to show that in practice more inclusive definitions of who should enjoy the right to the city are emerging, though not without their weaknesses and setbacks. In line with this, contributors to this thematic issue were asked to identify key institutions, agents, and interventions that sought to empower or facilitate social inclusion for migrants within the cities being researched. Our contributors include both scholars and practitioners, interested in exploring different forms of urban citizenship which have been enacted to overcome social exclusion in specific, and comparative, urban settings. The first priority for our contributors was to reflect on the way urban migrants organise and mobilise to enact their own citizenship rights within specific urban spaces, through engaging with various forms of politics, urban governance and service provision. The initiatives considered are mainly in Western European cities, and to a lesser extent in North America. The aim is to generate debate about the possibilities of civic engagement to generate spaces for political participation, and ways and means to protect and claim basic rights. These include the right to health and well-being, to physical and existential security, to work and a decent living, for non-citizens and national migrants alike, young and old, men and women. Specific examples come from The Netherlands, where both co-editors work and live, Belgium, Germany, Italy, France, Greece, the UK and the US. Individual articles are briefly presented discussed in the last section of this editorial introduction, which first outlines some of the guiding concepts and themes.

\section{Exclusion and Selective Citizenship}

Inhabitants of urban spaces enjoy highly variable life conditions, and different degrees of protection and neglect from municipal and central government institutions and actors. This means it is important to understand enacted citizenship struggles as a lens through which we can interpret efforts, mainly 'from below', to promote social inclusion, for example through collaborative encounters, dialogue, self-organising and even technology, all in ways that are rarely free of friction and conflict (Isin, 2013, p. 22). According to Isin (2013, p. 19), such processes of contestation and collaboration can generate "new affinities, identifications, loyalties, animosities and hostilities across borders" and within cities, which emerge as "new sites of struggle" as "citizenship is enacted through not only legal but also cultural, social, economic and symbolic rights, responsibilities and identifications." By focusing on 'enacted' citizenship struggles, we focus attention on how people and groups achieve, or fail to achieve, what they perceive as their legitimate claims for both recognition and resources. The notion of enacted citizenship is premised on the idea that "cities are shaped by people, but people are also shaped by cities" (van Niekerk, Hendriks, \& Duyvendak, 2009, p. 16), so that individuals and groups need to mobilise and 'enact' their citizenship in urban spaces, and do so in a context where they too are the objects of urban policies of various kinds of selective 'screening in' and 'screening out' (Hintjens, 2013).

Social inclusion is viewed as desirable to the extent that it makes it more possible for individuals and groups to exercise their rights through enabling their 'enacted' citizenship practices. Social exclusion is here defined as "the dynamic processes of being shut out, partially or fully, from any or all of several systems which influence the economic and social integration of people into their society" (Commins, 2004, p. 68). In this sense, social exclusion needs to be actively challenged at different levels since, in the widest sense, it "constitutes a de- 
nial of full citizenship-the collection of rights and responsibilities that one acquires as a member of society" (Connolly, 1999, as cited in Commins, 2004, p. 68). As the urban poor worldwide increasingly "inhabit a kind of no-man's land, consistently...'screened out' from basic human rights such as the right to work, to education or to health" (Hintjens, 2013, p. 88), the situation in the 'prosperous' cities of the North is arguably not much better than in some global cities of the South. In a practice-oriented definition designed for DFID, Beall and Piron (2005) define social exclusion as both "a process and a state," and stress that such processes and this state prevent individuals "from full participation in social, economic and political life and from asserting their rights", highlighting that "exclusionary relationships" are "based on power" (Beall \& Piron, 2005, p. 9).

In more recent years, the Council of Europe has noted a rise in extreme hostility towards migrants and minorities, as economic conditions across the EU have worsened and far-right populist parties have started to gain power, or a larger share of the vote (Council of Europe, 2012). Old as well as new EU member states are no strangers to a host of prejudices, including Islamophobia, anti-Gypsyism, racism and homophobia (Jovanovic, 2015). The impact of social exclusion is cumulative and multiple, with the excluded often suffering 'persistent disadvantage' in several areas of their lives, lacking not just adequate access to goods and services, which reinforces problems of poverty and the lack of satisfaction of their basic needs, but also very often a distinct "lack of security, lack of justice, lack of participation and representation" (Kurian \& Bedi, 2004). As Galtung's typology of violence suggests, social exclusion can even amount, over the longer term, to a form of structural violence where certain categories of "human beings are being influenced so that their actual somatic and mental realizations are below their potential realizations" (Galtung, 1969, p. 168). Social exclusion is often gendered, with women and LGBTs experiencing extra disadvantages. Under these circumstances, it could be argued that the excluded experience what has been referred to as 'hollow citizenship', characterised by democratic deficits and inequality in relation to their rights and entitlements:

Democracy will mean little to ordinary citizens (hollow citizenship) if they do not enjoy equal rights and entitlements as citizens whether because constitutional and legal arrangements fail to guarantee these rights, or because they are effectively excluded from the public sphere as a result of gender, societal inequalities, lack of organisation, cultures of intolerance or intimidation and violence." (Luckham, Kaldor, \& Goetz, 2000, p. 22)

Historically, exclusion from the benefits of emerging political citizenship, and then later from full economic and social citizenship, have rendered minorities and other vulnerable groups, such as the elderly and those physically, mentally and emotionally challenged, invisible to historians and policy-makers alike. The persecution of minorities is often by the state, including by state officials simply 'doing their job,' and indifference to suffering plays a part in the social exclusion process. Among undocumented migrants, for example, categories of people considered 'undeserving' are left out of full access to citizenship-related benefits and rights, something that can usefully be defined as 'colonial' (Zureik, 2011). Those considered more 'deserving' are given some support whilst they wait for a decision by the immigration authorities. Under the rule of law, open, sustained and deliberate social exclusion should not be possible. However, it seems that it is. Thus, people with irregular migration status have far fewer recognised basic rights-civil and political as well as economic and social-than other people, who have the right papers. The state of exception is for many minorities like a state of siege.

Indeed, often the best place to meet to discuss what government authorities are doing is across the widespread spatial segregation of disadvantaged. This makes it more difficult for them to access health care and other goods and services. Recourse to justice is one of the ways that minorities try to oblige the authorities to respect specific rights, including the right of nondiscrimination. Recourse to legal action can also be part of enacting citizenship for excluded and vulnerable minorities, ending the structural violence of economic and social exclusion of minority people from accessing what they need to maintain themselves, body and soul, and their economic and social rights.

\section{Urban Politics and the 'Right to Have Rights' in the City}

As Hannah Arendt famously noted, the "right to have rights" prioritises being a member of a political community as intrinsic to citizenship. In contemporary societies, citizenship in a formal sense, is often associated with the possession of a legal document, such as a passport for a particular country. While such credentials are important, the concept of citizenship can be viewed as a dynamic engagement to access the full entitlements and rights as a member of society. In his classic article of 1950, T. H. Marshall identified what he viewed as three elements of citizenship. The civil element constituted the right of persons to individual freedoms such as liberty, freedom of speech and religion as well as justice. The political aspects related to the right to participate in government institutions. Marshall (1950) gave special significance to social citizenship which included "the right to a modicum of economic welfare and security to the right to share to the full in the social heritage and to live the life of a civilized being according to the standards prevailing in the society." These aspects of citizenship are neither automatic nor even widely recognised as citizenship rights. On the contrary realization of these rights often 
requires negotiation and struggle, particularly in a context of competition for resources and increasing inequality in society.

As Arendt reminded us long ago there is a "discrepancy between the efforts of well-meaning idealists, who stubbornly insist on regarding as 'inalienable' those human rights which are enjoyed only by the citizens of the most prosperous...countries, and the situation of the rightless themselves" (Arendt, 1973, p. 279). Lefebvre expresses a similar notion when he explains that "the right to the city cannot be conceived of as a simple visiting right or as a return to traditional cities. It can only be formulated as a transformed and renewed right to urban life" (as cited in Kofman \& Lebas, 1996, p. 158). In urban settings, where municipal authorities are often delegated by central government to provide basic services, human rights may have least chance of being fulfilled. For those who live without the 'right to have rights,' exclusion from basic service and benefit provisions can lead them to protest. Their imperative becomes to break out of the status of being rights-deprived, and to enact their own citizenship by demanding a basic level of rights as inhabitants of the city (Isin, 2013, pp. 29-30). Intersectional relations of support among various excluded minorities can be very powerful politically, building cross-cutting alliances that can at first seem surprising. Thus Kruma \& Indans (2013) suggest that when gays and lesbians marched in a Pride parade through the city of Riga in Latvia, they too were enacting citizenship. In the process, they became political subjects and were able to express their own conception of their basic rights.

One increasingly relevant manner of dealing with exclusion and democratic deficits is through what John Gaventa (2006, p. 11) has referred to as the 'deepening democratic' approach: "a process through which citizens exercise ever deepening control over decisions which affect their lives, and as such it is also constantly under construction." He identifies four sub-schools within deepening democracy literature: 'civil society democracy,' which is associated with good governance and civil society advocacy, 'participatory democracy,' which implies the involvement of citizens at a local and national government level, 'deliberative democracy,' which emphasises the "nature and quality of deliberation" by citizens, and 'empowered participatory democracy,' which gives priority to bottom-up participation of citizens in the policies that affect their lives (Gaventa, 2006). As the author argues:

If we understand democracy not as a set of institutional designs, but as a concept constantly under construction through contestation amongst actors in different settings, then to support the process of democracy building we must also find and support emerging visions and imaginations of what democracy might become. (Gaventa, 2006, p. 27)

To place the emphasis on what minority and socially excluded groups can do to claim their 'rights to the city,' the term 'enacting citizenship' has proven especially useful, having been elaborated on by Isin (2013) among others. This concept suggests members of such minority groups should operate as if they were entitled to full inclusion in all the rights accorded to full citizens. Under such conditions, where law and politics, sociality and economy are all channels for claiming full citizenship rights, it is the very enacting of citizenship that produces particular rights-bearing subjectivities. Rather than assuming prior awareness of rights entitlements, as Isin notes:

The phrase 'acts produce subjects' indicates that events such as demonstrations, appeals, claims and so on create possibilities of acting in certain ways that otherwise would not be possible. This is different from assuming that subjects already exist before they act. The difference between bodies and subjects is important. (Isin, 2013, p. 23)

Struggles for full citizenship rarely come framed through the lenses of formal or specific human rights demands. Instead, they take the form of demands for practical access to services and procedural and historical justice. Through notions of enacted citizenship, it becomes apparent how such struggles go further than demanding citizenship rights, and actually start to enact new forms of citizenship, including in the urban setting. A number of the articles in this thematic issue illustrate how enacting citizenship can change the tenor of those making such demands and doing the enacting. In such cases "it is important to acknowledge that when people act, whatever differences may separate them in values, principles and priorities, they are enacting citizenship, even those who are not passport-carrying members of the state or the right state" (Isin, 2013, p. 22).

Whilst deterritorialised elites may be able to relocate themselves in times of trouble, "lower-tier city dwellers are 'doomed to stay local,"' even if they have been highly mobile as forced migrants (Bauman, 2003, p. 98). This thematic issue refocuses our attention on how (forced) migrant citizenship is being enacted so as to challenge these frequent situations of rightlessness in which 'lower-tier city dwellers' find themselves as urban residents, often without formal rights. What is explored by various contributions in this thematic issue is how "the city [as]...the dumping ground for anxieties and apprehensions generated by globally induced uncertainty and insecurity" can also become a city which is "a prime training ground where the means to placate and disperse that uncertainty and insecurity can be experimented with, tried out and eventually learned and adopted" (Bauman, 2003, p. 117).

\section{Comparative Reflections and Experiences}

In “Improvising 'Nonexistent Rights': Immigrants, Ethnic Restaurants, and Corporeal Citizenship in Suburban California," Lee (2019) suggests that: 
There is an urgent need to continue exploring ways to facilitate and expand democratic rights and participation for the urban inhabitants in these neoliberal times. Yet the way to engage this exploration needs to be connected with the present realities of the urban residents' everyday experiences of city life on the ground. (Lee, 2019, p. 80)

Through the example of 'ethnic' restaurants in California, Lee concludes that: "for many ethnic restaurateurs and workers, the realization of corporeal citizenship...is not limited to....but also carries a deeper, intangible dimension of affective inclusion, psychosomatic wellbeing, and sociocultural belonging" (Lee, 2019, p. 85), which he connects with some aspects of a now-fading shared belief in the American Dream.

The US was the home of the idea of cities of sanctuary, an idea considered by two articles in this thematic Issue, the first by Sébastien Lambert and Thomas Swerts. In "'From Sanctuary to Welcoming Cities': Negotiating the Social Inclusion of Undocumented Migrants in Liège, Belgium," Lambert and Swerts (2019) examine struggles for sanctuary status in Liege, Belgium, by an activist rights NGO and migrants in the city. The authors point to "both the potentialities and difficulties involved in turning radical political imaginaries into reality" (Lambert \& Swerts, 2019, p. 97). In this case, the outcome was more modest than it was hoped, since Liege Council "made it clear that they would only adopt a motion [carried officially] if it [was highlighted that] efforts... were already being undertaken to welcome migrants in Liège" (Lambert \& Swerts, 2019, p. 96). The result was that the Sanctuary city initiative, which would explicitly have protected 'sans-papiers,' was dropped and there resulted a more depoliticised and vague statement about Liege as a 'Welcoming city,' open to all newcomers.

In efforts to be more genuinely transformative, some promising initiatives have focused on extending health rights as a means to 'stretch' citizenship in the city. Such long-term, complex and nuanced struggles for health rights are widespread and exemplified in "Contested Health Care System in Berlin: Are Illegalized Migrants Becoming Urban Citizens?" by Wilcke and Manoim (2019).

As the authors explain, "the Medibüro...a grassroots initiative...has been fighting for equal access to medical care for all, for more than 20 years" (Wilcke \& Manoim, 2019, p. 101). Through a very recent initiative (from 2019), the so-called Anonymized Health Certificates were finally issued after many years of pressure by the government of Berlin. This helped extend medical care for illegalised migrants, in part on public health grounds. The initiative derived its wider legitimacy from a shared "procedural understanding of citizenship" among parts of the Berlin populace: There was the presumption that "migrants as active political subjects" were entitled to public health care (Wilcke \& Manoim, 2019, p. 101). Interestingly, Anonymized Health
Certificates were issued even though providing medical care for undocumented people remains illegal at federal and city level. Public health is not quite like other public services, since if governments or cities fail to ensure public health to the most vulnerable, including the undocumented, for instance by leaving communicable diseases undiagnosed and untreated, this increases health risks for everyone.

Reflecting on the processes of eHealth involved for one small set of elderly migrants in The Hague, Kurian, Menke, Santokhi, and Tak (2019) have combined academic and practitioner insights. Their article, "Enabling Social Inclusion and Urban Citizenship of Older Adults through eHealth: The iZi Project in the Hague," describes this pioneering, small-scale experiment for older adults, living in their own homes, and still in its early stages. This "three-year pilot was started in February 2016...in one street in the Escamp district" in the city, and "brought together a unique hub that connected residents, research institutions, governments, care and welfare organizations, and businesses in the field of health care innovation" (Kurian et al., 2019, pp. 111, 115). With home care budgets being slashed at the same time, the lofty aspirations of this e-health innovation were not met. However, by selecting and using smart technologies, elderly migrants were assisted to feel safer at home and perceived themselves as living in greater dignity, and in a stronger community (Benhabib, 2002, p. 464).

In 'Acts for Refugees' Right to the City and Commoning Practices of Care-tizenship in Athens, Mytilene and Thessaloniki," Tsavdaroglou, Giannopoulou, Petropoulou, and Pistikos (2019) view citizenship as "an ongoing and contested battlefield" of claims and counter-claims (Tsavdaroglou et al., 2019, p. 120). Moreover, as the authors suggest, "there is little research on mutual care as a form of commoning and especially...refugees' self-care practices which offer the potentiality to reinvent both the right to the city and new forms of citizenship acts" (Tsavdaroglou et al., 2019, p. 122). This is a gap that the article seeks to address. Selforganised camps and safe spaces for refugees, backed by solidarity organisations, which range from anarchists to NGOs, are the main concern of this article, which focuses on two cities in Greece. The article reminds us, following Arendt (1970), that "it is the function...of all action...to interrupt what would otherwise have proceeded automatically, and therefore predictably" (Arendt, 1970, p. 31). However, the authors are anything but complacent about the possibilities for self-organising and solidarity politics in the wider context of Greece, with rising xenophobia (see also Swarts \& Karakatsanis, 2013).

Travelling to the Netherlands, via Italy, Angelucci's (2019) "Spaces of Urban Citizenship: Two European Examples from Milan and Rotterdam" shows how initiatives by local supporters of refugees in each city produced distinct, yet very comparable, outcomes. Whereas, "in Milan, the main role [of reception] is played by gendered roles and practices which express 
themselves in mothering and childminding activities...in Rotterdam the basic element is the contraposition to market-driven logics by the means of green and social activities" (Angelucci, 2019, pp. 138-139). Despite such differences in outcome, Angelucci suggests both sets of citizen initiatives for refugees and the undocumented, had in common their distance from the urban authorities who actually make policy and mediate between the global, the national and the local. On a realist note, she concludes that "being lived and perceived as a private dimension, these spaces do not have any public or political weight" (Angelucci, 2019, p. 139). Indeed, she concludes, "they are not...even [being] listened to at the political and administrative levels" of decision-makers in each city (Angelucci, 2019, p. 139).

This critical note is continued in the article by Wilcock (2019), "Hostile Immigration Policy and the Limits of Sanctuary as Resistance: Counter-Conduct as Constructive Critique." Focusing on the City of Sanctuary movement as the "most institutionalised form of resistance" to the hostile environment policy of the national UK government towards undocumented migrants, the author points out that, "the extent to which [the City of Sanctuary movement]...can resist the hostile environment has been seriously questioned," given the generally apolitical stance adopted by its adherents (Wilcock, 2019, p. 143; emphasis in original). Proposing the Foucauldian notion of counter-conduct, resistance to governmentality, she makes visible those who tend to be ignored in the City of Sanctuary framing of 'innocent' asylum seekers, including undocumented migrant workers and single men, in the context of a government which asks employers, landlords, academics, doctors and the general public to police the lines between 'good' and 'bad' migrants. Starting from a critical point of view, she employs Foucault to good effect and concludes that it is still "within the power of the [City of Sanctuary] movement...to resist being the judgemental citizen through enacting alternative non-judgemental political subjectivities and encouraging others to do the same" (Wilcock, 2019, p. 148; emphasis in original).

Finally, in "Diasporic Civic Agency and Participation: Inclusive Policy-Making and Common Solutions in a Dutch Municipality," Ong'ayo (2019) bases his findings on the African diaspora in The Hague and suggests that resistance to enacting citizenship rights for members of this diaspora, depends on their formal political participation in decision-making in the city, and especially in the affairs of the municipality. Reflecting on a number of initiatives by Sub-Saharan African diaspora organisations in The Hague and on how they "make use of political opportunity structures and policy windows to influence policy in different policy spaces," whether invited, claimed or self-organised, this article deals head-on with the issue of political and democratic participation of a dispersed, internally diverse diasporic grouping (Ong'ayo, 2019 , p. 159). Unlike some other diasporic groups, the home states of most African migrants do not have special provisions to ensure that they do not become stateless or lose their nationality (see, for example, for the Turkish case, Yanasmayan \& Kaşlı, 2019). As Ong'ayo found, despite this, the diaspora found it relatively easy to reach agreement with The Hague municipality regarding everyday issues like Dutch language classes, training, health or sport (perhaps the easiest of all). On issues of citizenship, legal status and full 'belonging' to the city, however, there were major contestations in discussions between the African diasporic groups and the municipality. In other words, whilst leaders of Sub-Saharan African diaspora groups in the 'City of Peace and Justice' were recognised as bridge-builders and interlocutors for their communities, their concerns about those of their number without formal legal residency, could not be met. Besides some minor allocation of resources resulting from dialogue, it remained beyond the municipality's staff's comfort zone to recognize all those who compose the SubSaharan African diaspora in The Hague, including those who are undocumented, for example.

\section{Conclusion}

In conclusion it is to be hoped that this thematic issue as a whole helps illustrate and think through local urban practices of enacted citizenship citizenship. As Isin reminds us, this involves recognising "that to be a citizen is to make claims to justice: to call already defined orders, practices and statuses into question" (Isin, 2013, p. 43). As he puts it, this vision of "activist citizens opening the gates of the city and introducing rupture into the order of things by claiming justice" has both historical resonance and wider relevance to non-citizens as well (Isin, 2013, p. 43). The overall focus has been on some recent urban-based initiatives seeking improved protection, well-being and health for socially excluded and marginalised groups, especially for migrants with different forms of legal status under the law. Most of these experiments involve 'local' citizen initiatives, and many also involve self-organising by migrants themselves. Whether older or younger, women or men, citizens or undocumented, those involved in the quest for the 'right to the city,' often live without formal rights, and many cannot travel freely; some cannot even leave the city. Their daily experience of urban life is mostly one of being 'rooted to the spot,' as they find themselves imprisoned from within by "a borderless economy and a barricaded border" (Andreas, 2000, p. x), or even, less dramatically, by old age.

Unable to leave the local spaces, their imperatives are to enact citizenship within the urban setting, as much a strategy for survival as for rights as such. For some only full legal citizenship can help them escape the confines of the "fragmented, localised, and thus increasingly powerless" space of places, to taste some benefits of the "versatility of the space of flows" (Bauman, 2003, p. 101). They may do this by moving, living and working elsewhere, or through enjoying recognition, protection and a wider range of rights in the city where they already are. 


\section{Acknowledgments}

We acknowledge the support of the International Institute of Social Studies for a panel we jointly organized at the conference of the Institute of Housing and Urban Development Studies (HIS) in collaboration with the Erasmus Vital Cities initiative, 'Empowering Cities \& Citizens.' Held in Rotterdam on 6-7 November 2017, this event helped kick-start this thematic issue. We are grateful to anonymous reviewers for all their comments on the various contributions, and to the Editor of Social Inclusion for her dedication to seeing this through.

\section{Conflict of Interests}

The authors declare no conflict of interests.

\section{References}

Andreas, P. (2000). Border games: Policing the U.S.Mexico divide. Ithaca, NY: Cornell University Press.

Angelucci, A. (2019). Spaces of urban citizenship: Two European examples from Milan and Rotterdam. Social Inclusion, 7(4), 131-140.

Arendt, H. (1970). On violence. London: Harcourt.

Arendt, H. (1973). Origins of totalitarianism. New York, NY: Harcourt Brace.

Bauman, Z. (2003). Liquid love: On the frailty of human bonds. Cambridge and Malden, MA: Polity.

Beall, J., \& Piron, L.-H. (2005). DFID Social exclusion review. London: LSE and the Overseas Development Institute (ODI). Retrieved from https://www.odi. org/sites/odi.org.uk/files/odi-assets/publicationsopinion-files/2301.pdf

Benhabib, S. (2002). The claims of culture: Equality and diversity in the global era. Princeton, NJ: Princeton University Press.

Commins, P. (2004). Poverty and social exclusion in rural areas: Characteristics, processes and research issues. Sociologica Ruralis, 44(1), 60-75.

Council of Europe. (2012). Human rights of Roma and travellers in Europe. Strasbourg: Council of Europe. Retrieved from https://www.coe.int/t/ commissioner/source/prems/prems79611_GBR_ CouvHumanRightsOfRoma_WEB.pdf

Galtung, J. (1969). Violence, peace and peace research. Journal of Peace Research, 6(3), 167-191.

Gaventa, J. (2006). Triumph, deficit or contestation? Deepening the 'deepening democracy' debate (IDS Working Paper No. 264). Brighton: Institute of Development Studies.

Hintjens, H. (2013). Screening in or out? Selective nonsurveillance of unwanted humanity in EU cities. Surveillance \& Society, 11(1/2), 87-105.

Isin, E. (2013). Claiming European citizenship. In E. Isin \& M. Saward (Eds.), Enacting European citizenship (pp. 19-46). Cambridge and New York, NY: Cambridge University Press.
Jovanovic, Z. (2015, September 21). Why Europe's 'Roma decade' didn't lead to inclusion. Open Society Foundations. Retrieved from https://www. opensocietyfoundations.org/voices/why-europe-sroma-decade-didn-t-lead-inclusion

Kofman, E., \& Lebas, E. (Eds.). (1996). Writings on cities. Oxford: Blackwell Publishers.

Kruma, K., \& Indans, I. (2013). Negotiating otherness: Mozaika and sexual citizenship. In E. Isin \& M. Saward (Eds.), Enacting European citizenship (pp. 84-110). Cambridge and New York, NY: Cambridge University Press.

Kurian, R., \& Bedi, A. (2004). Poverty, gender and social exclusion in Mauritius. Unpublished report prepared for the African Development Bank.

Kurian, R., Menke, N., Santokhi, S., \& Tak, E. (2019). Enabling social inclusion and urban citizenship of older adults through eHealth: The iZi Project in The Hague. Social Inclusion, 7(4), 108-118.

Lambert, S., \& Swerts, T. (2019). 'From sanctuary to welcoming cities': Negotiating the social inclusion of undocumented migrants in Liège, Belgium. Social Inclusion, 7(4), 90-99.

Lee, C. T. (2019). Improvising "nonexistent rights": Immigrants, ethnic restaurants, and corporeal citizenship in Suburban California. Social Inclusion, 7(4), 79-89.

Luckham, R., Kaldor, M., \& Goetz, A. M. (2000). Democratic institutions and politics in contexts of inequality, poverty and conflict: A conceptual framework (IDS Working Paper 104). Brighton: The Institute of Development Studies.

Marshall, T. H. (1950). Citizenship and social class and other essays. Cambridge: Cambridge University Press.

Ong'ayo, A. O. (2019). Diasporic civic agency and participation: Inclusive policy-making and common solutions in a Dutch municipality. Social Inclusion, 7(4), 152-163.

Swarts, J., \& Karakatsanis, N. M. (2013). Challenges to desecuritizing migration in Greece. Journal of Balkan and Near Eastern Studies, 15(1), 97-120.

Tsavdaroglou, C., Giannopoulou, C., Petropoulou, C., \& Pistikos, I. (2019). Acts for refugees' right to the city and commoning practices of care-tizenship in Athens, Mytilene and Thessaloniki. Social Inclusion, 7(4), 119-130.

van Niekerk, M., Hendriks, F., \& Duyvendak, J. W. (2009). City in sight: Dutch dealings with urban change. Amsterdam: Amsterdam University Press.

Wilcke, H., \& Manoim, R. (2019). Contested health care system in Berlin: Are illegalized migrants becoming urban citizens? Social Inclusion, 7(4), 100-107.

Wilcock, C. A. (2019). Hostile immigration policy and the limits of sanctuary as resistance: Counter-conduct as constructive critique. Social Inclusion, 7(4), 141-151.

Yanasmayan, Z., \& Kaşlı, Z. (2019). Reading diasporic engagements through the lens of citizenship: Turkey as a test case. Political Geography, 70, 24-33. 
Zureik, E. (2011). Colonialism, surveillance, and population control: Israel/Palestine. In E. Zureik, Lyon, D., \& Abu-Laban, Y. (Eds.), Surveillance and control in Is-
rael/Palestine: Population, territory and power (pp. 3-44). Oxford and New York, NY: Routledge.

\section{About the Authors}

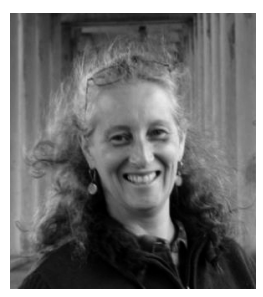

Helen Hintjens is Assistant Professor in Development and Social Justice at the Hague-based International Institute of Social Studies (ISS), of Erasmus University Rotterdam, Netherlands. For more than 30 years she has researched comparative asylum and migration policies of EU member states in the context of broader post-colonial relationships and ideas. Her particular interests are in proasylum advocacy networks, selective urban surveillance of undocumented rejected asylum seekers, networks of 'cities of sanctuary,' and organised resistance to deterrence-based destitution, detention and forced deportation. Her regional focus includes the African Great Lakes region, especially Rwanda and Eastern DRC, in relation to identity politics and post-genocide recovery. She used to work on small, non-sovereign islands of the Indian Ocean and Caribbean, long ago. She now increasingly works on peace-building through music and the arts, to tackle legacies of unfinished decolonisation both in Europe and in East Africa.

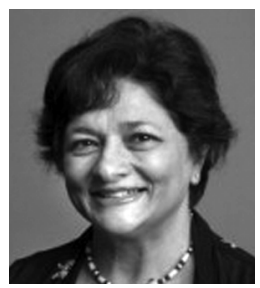

Rachel Kurian is an International Labour Economist at the International Institute of Social Studies of the Erasmus University Rotterdam. She holds degrees in Mathematics and Economics, and has studied at Madras University, Jawaharlal Nehru University, New Delhi, University of Cambridge, UK, and the University of Amsterdam, where she completed her PhD in 1989. Her teaching, research, project and consultancy work have focused on trade unions, gender politics, women and child workers, social exclusion, human rights, poverty and labour in the context of economic restructuring. She has field experiences in Asia (Sri Lanka, India, Malaysia, Philippines, Thailand, South Korea), Latin America (Colombia, Peru, Chile, Ecuador), Caribbean (Trinidad and Tobago, Barbados) Africa (Mauritius, Tanzania, South Africa, Zimbabwe), Western Asia (Israel. Palestine) Europe (Netherlands, France) and Western Balkans. 